\title{
INVESTIGATING THE NEXUS BETWEEN PERSONALITY TRAITS AND ISLAMIC WORK ETHICS
}

\author{
Mastura Ab. Wahab \\ School of Management, Universiti Sains Malaysia, \\ 11800 USM Pulau Pinang, Malaysia \\ E-mail: mastura.ab.wahab@usm.my
}

Published online: 30 June 2017

To cite this article: Wahab, M.A. (2017). Investigating the nexus between personality traits and Islamic work ethics. Asian Academy of Management Journal, 22(1), 183-213. https://doi.org/10.21315/aamj2017.22.1.8

To link to this article: https://doi.org/10.21315/aamj2017.22.1.8

\begin{abstract}
This study examines the nexus between personality traits and Islamic work ethics (IWE) among employees in Malaysia. The data were drawn from 182 participants who completed a 36-item personality traits questionnaire and the short version of the 17-item IWE questionnaire. Data were analysed using Smart PLS version 3.2. Instead of using IWE as one composite factor which was normally done in most previous studies when researching on IWE, the present study has factor analysed the IWE and the result has generated three dimensions of IWE. The three dimensions were used as IWE's factors to test the relationships with the personality traits. The findings of the study revealed that the personality traits of openness-to-experience is a positive significant predictor of effort and competition dimensions of IWE, agreeableness is a significant positive predictor of effort dimension, while emotional instability is a negative predictor of effort dimension of IWE. The practical implication is for managers to use the finding of this study when hiring employees for jobs that require high ethical effort, competitiveness, and socially responsible work practices in their organisations. Another implication of the study is for organisations to consider some adjustments in interpreting the results when measuring the personality traits of the Muslim employees using current personality traits as developed in the West because Muslims interpret personality traits differently from the non-Muslim context.
\end{abstract}

Keywords: personality traits, Islamic work ethics, emotional instability, neuroticism, conscientiousness, agreeableness, openness-to-experience, extraversion

(C) Asian Academy of Management and Penerbit Universiti Sains Malaysia, 2017. This work is licensed under the terms of the Creative Commons Attribution (CC BY) (http://creativecommons. org/licenses/by/4.0/). 


\section{INTRODUCTION}

The relationship between personality traits and ethics has some rational and constructive foundations. Personality normally concerns the aspects of an individual's thought and behaviour that are stable over time and consistent across different situations (Walumbwa \& Schaubroeck, 2009), while ethics are a set of values and principles accepted by a person or a group (Anas \& Mounira, 2009); thus, both ethics and personality are constant variables that could impact behaviour in the workplace. Many previous studies have treated personality and ethics as relatively distinct subjects of inquiries; however, recent studies such as those by Walumbwa and Schaubroeck (2009), and Kalshoven, Den Hartog, and De Hoogh (2011) have shown consistent predictable correlations between personality and ethics. Major theories in ethics such as leadership and consumer ethics as well as trait activation theory have also suggested that relationships existed between personality and ethics (McFerran, Aquino, \& Duffy, 2010; Xu, Yu, \& Shi, 2011). However, many of the existing studies are only interested to examine the effect of conscientiousness, neuroticism, and agreeableness types of personality on ethical behaviour and excluded extraversion and openness-to-experience traits. With regard to the relationship with religiosity, the extant studies were quite limited and normally descriptive. Unethical embezzlement and practices in organisations are said to result due to the dissociation with the religious principles (Khan, Nazeer, \& Naqvi, 2015). The organisation also can incur higher loss if ethical issues are not resolved. Personality studies have been researched cross-culturally in many diverse areas and the findings proved reliable and valid. Conscientiousness type of personality for instance is regarded as among the most robust predictor of the work outcomes (Prewett, Brown, Goswami, \& Christiansen, 2016), thus using personality traits to predict ethical predisposition would give insights on what personality traits to be hired, especially in jobs that require high ethical practices such as those involving honesty, integrity, and transparent relatedness. Behaviour ethics literature also acknowledged that people with certain personality traits are more likely to behave ethically or unethically (Greenbaum, Hill, Mawritz, \& Quade, 2014). This study aims to examine whether certain types of personality traits relate more to ethical behaviour, ethical activities in general, and Islamic work ethics in particular. Ethical predisposition refers to the cognitive framework that individuals use when making moral or ethical related decisions (Reynolds, 2006). It is important to see whether personality traits could influence individual tendency to involve in Islamic ethical or unethical behaviours. Nowadays, spirituality and religiosity are one of important aspects that influence many employees' work performance especially among Muslims (Achour, Nor, \& Mohd Yusoff, 2016). 
Religiosity was found essential to improve employees' well-being and reduce the amount of stress experienced in the work place (Uddin, Ali, \& Ali, 2016). Thus, understanding how religious work ethics such as Islamic work ethics (IWE) work in relation to individuals' personality traits would offer more insights into the effect of religious work ethics on employees' behaviour in the workplace.

Personality was defined as an individual's stable and consistent thoughts and behaviour across different situations (Walumbwa \& Schaubroeck, 2009). These individuals can be religious as well as non-religious. A religious individual with religious and ethical beliefs may think and behave differently from a non-religious individual; thus, individual differences in religious ethics, attitudes, beliefs, and practices are supposed to reflect differences in personality traits (Saroglou \& Munoz-Garcia, 2008). Likewise, a Muslim may differ from a non-Muslim in terms of personality traits and work ethics. With regard to work ethics in particular, Islam requires Muslims to lead their lives according to the Islamic legal code of shariah (Anas \& Mounira, 2009). In Islam, ethics is given the highest emphasis and it governs all aspects of Muslim lives (Hassan, 2002). The teachings of Islam strongly stress the observance of ethical values and moral principles regarding human behaviour, which can be found throughout the holy Quran and the sunnah (Yousef, 2001). Hence, Muslims' attitudes and their ethical predispositions are inevitably influenced by the IWE derived from Islamic teachings either fully or partially. Notwithstanding, research on the influence of personality on Islamic ethics is scarce.

Studies have widely reported that the five personality factors such as neuroticism, extraversion, and conscientiousness are good predictors of career success (Judge, Higgins, Thoresen, \& Barrick, 1999); in particular, conscientiousness is the most consistent personality trait predicting performance across jobs (Cubel, NuevoChiquero, Sanchez-Pages, \& Vidal-Fernandez, 2016). Personality traits have been shown to consistently predict performance and career success; hence, using personality traits to predict the IWE can help establish that being ethical can be predicted based on certain personality traits, and in particular, to determine that IWE is influenced, among other factors by an individual's personality traits. If certain personality traits such as conscientiousness are reliable predictors of certain work outcomes, it is thus not surprising if ethical predispositions and IWEs could also be predicted based on personality traits. This will enrich the literature on personality traits and could add knowledge to the field of Islamic management and ethics. 


\section{REVIEWING EXTANT STUDIES}

\section{Personality Traits and the Relationship with Ethics, Religiosity, and Islam}

The big five personality can be considered as the most widely used and extensively researched model of personality traits (Woods \& Anderson, 2016). According to the big five personality framework, most individual differences in human personality can be classified into five empirically derived factors (Gosling, Rentfrow, \& Swann Jr., 2003) namely extraversion (e.g., positive, energetic, sociable), conscientiousness (e.g., self-disciplined, orderly), agreeableness (e.g., friendly, cooperative), openness-to-experience (e.g., open to new ideas and change), and neuroticism or emotional instability (e.g., insecure, vulnerable to stress) (Andreassen, Hetland, \& Pallesen, 2010).

\section{Conscientiousness}

Conscientiousness is one of the most robust predictor of personality traits on work outcomes. A conscientious person has traits such as hardworking, persistent, wellorganised, and goal oriented (Camps, Stouten, \& Euwema, 2016). The relationship between conscientiousness and ethical predisposition is generally positive (Bratton \& Strittmatter, 2013), where conscientiousness was found to link positively with ethical use of internet facility (Karim, Zamzuri, \& Nor, 2009) and ethical leadership (Kalshoven et al., 2011). Conscientiousness has also been reported to correlate negatively with dishonesty and cheating (Bratton \& Strittmatter, 2013). Meanwhile, Cooper, Slaughter, and Gilliland (2014) also reported that unethical behaviour has negative effects on conscientious personality traits. On the other hand, the relationship between conscientiousness and religiosity was also supported. A study by Taylor and MacDonald (1999) found that conscientiousness is related positively with religion. The relationship between conscientiousness and religiosity as well as spirituality was also unravelled (Wisker \& Rosinaite, 2016; Womble, Labbe, \& Cochran, 2013). In addition, conscientiousness was also found to have relationships with environmental as well as with prosocial behaviour activities (Saroglou, 2012).

However, the nexus between conscientiousness and IWE has not been explored by related studies. Few studies such as Othman, Hamzah, and Hashim (2014) regarded conscientiousness as the fundamental personality trait of a religious person regardless of culture. Hence, they proposed it to be an Islamic personality construct. Conscientiousness consists of traits such as exerted control, selfdisciplined, organised, reliable, and hardworking (Bratton \& Strittmatter, 2013). Therefore, individuals with conscientiousness are believed to be responsible 
and tend to refrain from committing evil. Enjoining good and avoiding sin are an example of conscientiousness personality traits in Islam. The Quran (5:44) mentions, "Let there arise out of group of people inviting to all that is good enjoining what is right and forbidding what is wrong. They are the one who attain success." On the other hand, those who have low conscientiousness are less organised, lack motivation, low in ambition, and therefore tend to procrastinate. These characteristics of individuals normally will result in increased propensity to cheat or behave unethically. In the context of Islam, individuals who do not refrain from committing sins and do not seek Allah's forgiveness after committing misdeeds are considered as having low Islamic personality of conscientiousness. Therefore, high conscientiousness is likely to lead to higher IWE association.

\section{Agreeableness}

Agreeableness is the personality trait characterised by friendliness, cooperativeness, modesty, kindness, considerate, and helpful towards others (Camps et al., 2016). These characteristics have been found to relate positively with ethical predisposition, especially among leaders (Walumbwa \& Schaubroeck, 2009). Agreeable people also prefer to compromise in dealing with conflicts and to avoid provocations or aggressiveness. In contrast, individuals with low agreeableness personality show lack of concern for others, tense, irritable, and rebellious, thus they tend to display unethical behaviour. Hong, Koh, and Paunonen (2012) found that low agreeableness is a prolific predictive factor of willingness to make unethical choice. Karim et al. (2009) in the study on personality and internet facility misuse also found that individuals with high agreeableness personality are less likely to engage in unethical and fraudulent behaviour, and high agreeableness is considered a good predictor of ethical predisposition. Agreeableness also has been mentioned as an important determinant of prosocial behaviour and volunteerism and correlates significantly with benevolent values (Motowidlo, Ghosh, Mendoza, Buchanan, \& Lerma, 2016). Individuals higher on agreeableness make more social investments in work, family, religion, and other prosocial activities (Saadullah \& Bailey, 2014). Agreeableness has also been found to relate highly to spirituality (Womble et al., 2013), religious values (Wisker \& Rosinaite, 2016), and religiosity (Aghababaei, 2013). Individuals who have strong belief in spirituality and religiosity have been found to possess high agreeableness and conscientiousness (Aghababaei, Błachnio, Arji, Chiniforoushan, Tekke, \& Mehrabadi, 2015).

Many individuals who are practising intrinsic religious values and orientations possess conscientiousness and agreeableness personality. People with agreeableness personality trait have also been described as people-oriented and are high in their social relations as they have emphatic inclination towards others and are found to 
be consistent with many religious orientations. Some studies have also attempted to relate agreeableness with Islamic personality. For example, Othman et al. (2014) considered conscientiousness and agreeableness as indispensable parts of Islamic personality. The traits of agreeableness seem to have some agreements with the teaching of Islam. For example, Islam preaches the practice of consultation regarding all worldly as well as religious matters. Practising consultation needs agreeableness from the members on issues discussed. Allah says in the Quran (42:30) that "their matters are shūrā among them" indicating the emphasis of agreeableness practice in Islam.

\section{Extraversion}

Extrovert possesses the personality traits of friendliness, socialibility (outgoing and gregarious), assertiveness, active, and impulsive (Bratton \& Strittmatter, 2013). The opposite of extrovert is introvert; among the characteristics introverts are that they are reserved, they do not like parties or hangouts and love to read alone (Javed, Nazam, Ahmad, \& Nadeem, 2014). Research has shown mixed findings about the relationship between extraversion and individuals' predisposition towards work ethic. Studies such as Bratton and Strittmatter (2013) found no relationship between extraversion and ethical tendency. Others such as Park, Blenkinsopp, and Park (2014) found a positive relationship between extraversion and whistle blowing predisposition. This may be due to the fact that extroverts are outspoken, dynamic, and dominant; thus, they feel more comfortable to voice their conscience (moral identity). Yet, according to Saroglou and Munoz-Garcia (2008), individuals with extrovert personality are excitement seeking, therefore are negatively related to benevolence. Instead, they are more inclined towards the opposite of conformity and rule binding. However, some studies such as Saadullah and Bailey (2014) found no significant association between extraversion and ethical behaviour.

In terms of relationship between extraversion and religiosity, recent research is very limited. According to Aghababaei (2013), extroverts relate less negatively to religiosity. Older studies such as Robinson (1990) and Francis (1992) were in favour of associating extraversion with religiosity negatively. Especially, Robinson (1990) has indicated that introverts adhere more strongly to religious principles than extroverts. However, in a Muslim context, extraversion and openness-to-experience are viewed differently. Many aspects of extraversion such as enjoying parties, being gregarious, and lacking of reading and studying are the opposite of Islamic ways of socialisation. Also, women in Islam are required to cover their 'aürah (intimate parts of the body) and to dress modestly, and they are prohibited to freely mingle around with the opposite sex out of marriages; therefore, these Islamic behaviour traits are in contrast with extraversion traits 
(Othman et al., 2014). In other words, extraversion is negatively associated with certain element of Islamic teachings. However, some extrovert traits are found to be in line with Islam teachings. For example, Islam emphasises the role of morality both in interpersonal and intrapersonal relationship, especially when dealing with people; this may be in accordance with the trait of extraversion that originates in the West. However, Islam forbids Muslims to be blunt and socially or verbally hurt other people's feeling as mentioned in a hadith which Prophet Muhammad (pbuh) said, "Whoever believes in Allah and the Last Day should speak good things or keep silent. Whoever believes in Allah and the Last Day, should be courteous and generous to his neighbour" (Sahih Bukhari and Muslim). Umar ibn al-Khattab also said, "The one who speaks a lot commits a lot of mistakes. The one who makes lots of mistakes commits lots of sins. The one who commits lots of sins will have the Hell-fire as the first place for him" (Zarabozo, 1999). However, although speaking the truth is preferable, some may not like it, such as the example in the hadith reported in Musnad Ahmad, "A word of truth in front of a tyrannical ruler." Islam encourages being good in words, speech, intention, and actions. Sufism scholars during the Islamic golden age, for example, are masters of speech eloquence. Islam also encourages Muslims to treat guests, neighbours, and elderly nicely and insisted that we be friendly to them. Introversion is not considered as an undesirable trait in Islam. However, introverts are considered as people with brain who think using 'aql (intellect), rather than do meaningless talking and socialising. The Islamic model of personality emphasises a balance between extraversion and introversion traits.

\section{Openness-to-experience}

The traits of people with openness-to-experience personality are open to change and new ideas. They are not afraid of exploring new things, and are acceptable to difficulties and challenging environment. They are also curious about things and will adopt new products more quickly than those with less openness-to-experience (Quintelier, 2014). However, ethical literature on openness-to-experience found no established positive relationship between openness-to-experience and ethical behaviour. Some studies such as that of Bratton and Strittmatter (2013) did not include openness-to-experience when studying the relationship between personality traits and intention to cheat. Camps et al. (2016) stated that high openness-to-experience is negatively related to hostility, but positively correlated with tendency to engage in verbal aggression. These mixed results are also found in some other studies such as that of Saadullah and Bailey (2014) which suggested that openness-to-experience is closely associated with moral reasoning and thought. A recent study by Wisker and Rosinaite (2016) found that religious values correlate positively with openness-to-experience and conscientiousness as well as 
agreeableness. This is inconsistent with the result of a previous study conducted by Johnstone, Yoon, Cohen, Schopp, McCormack, Campbell, and Smith (2012) who reported that Muslims are least open to new experience.

Overall, not many recent studies have been found to examine the relationship between openness-to-experience and religiosity. Furthermore, openness-toexperience in Islamic social context is perceived quite differently by the West. Like extraversion, openness-to-experience was associated negatively with Islam, especially when Islamic religion preaches modesty and abidance by the shariah law which details evidence (qat'î) clearly articulated in the Quran and sunnah. In general, Islam highly encourages Muslims to possess openness-to-experience personality traits especially in relation to work activities. Numerous Islamic work values such as itqān (perfection) and ihsān (benevolence) are core Islamic work values which are highly emphasised to be practised by Muslims and encouraging them to be creative in many new areas of work activities. Only in regard to huküm (rules) and 'ibādah (ritual worship), which have elusive evidence (qat'i) in the Islamic sources, then openness-to-experience is restricted. Similarly, being openness-to-experience to the extent of changing Allah's perfect creations such as performing plastic or surgical surgery merely to look younger or prettier or changing the words in the Quran is totally forbidden. The perfect creations of the Great Creator cannot be 're-perfected' without causing further destruction (mufsadah). However, there are things that Allah has left for human beings to use their intellect ('aql) and encourage them to explore and to be creative, in arriving at rulings (hukum) that are not found in the Islamic legal texts. For such things, Muslims are encouraged to use reasoning, analogy or ijtihäd. For example, in a military strategy, Salman al-Farisī suggested to the Prophet to dig a trench in battle of khandaq, while in another case, when Saladin suggested the building of a naval ship.

\section{Neuroticism or emotional instability}

Emotional instability or neuroticism is the opposite of emotional stability in which people possess the personality traits of being anxious, unstable, stressed, and impulsive (Kalshoven et al., 2011). Individuals high on neuroticism tend to experience negative moods such as anxiety, fear, depression, and irritability as well as other physical symptoms. In many studies, neuroticism has been found to be the significant predictor of unethical behaviour (e.g., Camps et al., 2016; Walumbwa \& Schaubroeck, 2009). People high in neuroticism are insecure, deprived, angry, frustrated, and moody; thus, are more susceptible to negative emotions. As a result, they may be involved in unethical activities. Neurotic individuals tend to be hostile towards others (Brown \& Treviño, 2006) and more defensive in their social 
interactions, which run completely opposite to the concepts of work ethic (Barrett \& Pietromonaco, 1997). Conversely, emotionally stable individuals normally value morality, loyalty, and obedience to norms. They have a sense of direction and are altruistic and emphatic (Karim et al., 2009). Therefore, they are more rational in their actions and less likely to resort to unethical behaviour in achieving their desired goals.

The relationship between neuroticism and unethical predisposition also received support from many writings in Islam such as Yasein (1998) and Akhir (2010). Islam values truthfulness and seeks harmony among values, intentions, and actions. In Islam, individuals who suffer emotional instability are advised to seek Allah's forgiveness and to repent of all their misdeeds; they are also encouraged to read the Quran, pray regularly, practise $d h i k r$ (the remembrance of Allah), and seek help from Muslims' religious experts ('ulamā') to find peace and guidance. Emotional stability can be realised if Muslims adhere to Allah's commands by refraining from doing sins and enjoining doing good. Islam means peace and giving total submission to Allah, signifying the relationship between emotional stability and Islam. In relations to this, Ibn al-Qayyīm stated that in every human heart there exist twists that cannot be disentangled except through total submission to Allah. Furthermore, all concerns and worries cannot be wiped off except by Allah's love and mercy (al-Misri, 2013) as Allah says in the Quran (67:97), "whoever does righteousness, whether male or female, while he is a believer, We will surely cause him to live a good life" indicating the importance of religion as a determinant factor to achieve emotional stability.

\section{Pillars of IWE}

The IWE is an orientation that shapes and influences Muslims in the workplace (Ali \& al-Owaihan, 2008). It is an ethical guidance for Muslim employees on how to ideally perform the job as required by Islam. IWE is among the factors that have an immense influence on Muslim employees and Islamic organisations. IWE is built on four primary concepts, namely effort, competition, transparency, and morally responsible conduct, which become the pillars of IWE (Ali, 2005).

Effort as a concept behind IWE relates to the importance of working hard and putting effort. It is a rule of nature that success can only be achieved by working hard and giving commitment to the job. Effort and hard work in general is a source of self-respect, satisfaction, and fulfilment for human being. Umar ibn al-Khattab, a second rightful guided caliph used to say, "I would prefer dying while struggling for my sustenance and the sustenance of my children, to dying while fighting in the defence of faith." In another occasion Umar used to say, "The strength of any 
deed is not to postpone today's work to tomorrow." Work is considered 'ibädah (worship) in Islam and will be rewarded, as the Prophet Muhammad (pbuh) said, "Worshipping has seventy avenues, the best of them is the involvement in an honestly and earned living."

Transparency is considered a pillar of IWE. It is built on good values such as honesty, sincerity, integrity, trustworthiness, and justice. Thus, any defective conducts and acts of deceptions are considered against the transparency pillar of IWE. Transparency also relates to akhlaq or good character and credibility involving people either in business, economic, or any affairs related to responsibility and liability entrusted. Islam advocates sellers beware; thus, when sellers or workers are involved in trading or performing work activities, their duties are to make sure all products or work are of good quality. This is based on a hadith in which Prophet Muhammad (pbuh) said, "He who cheats is not one of us." Transparency is not just involving actions but also intentions. It is one of the vital criteria with which work should be evaluated in Islam. Thus, any work activities perceived to be harmful or even that would result in significant wealth to certain people like monopoly in business is considered unlawful.

IWE also put a high emphasis on morally responsible behaviour such as ethical conduct. Ethic is a precondition to having a prospering economy and sustainable community. Ethical working climate or morally responsible behaviour is good for the economy, the employees, the organisation, and the society as a whole. Ethics in Islam is inseparable from work, economy, and religion. Individuals wanting to achieve prosperity in worldly economy or in religion must uphold ethical values and orientations prescribed by Islam.

Apart from hardworking and striving for sustenance in life, IWE is also built on pillars associated with competition. This is mentioned in the Quran (62:10), "Disperse through the land and seek God's bounty." However, the Islamic way of competition is not merely to outperform others, instead it must be conducted in such a way as not to inflict any intentional damage to others (Ali, 2005) as the Quran (49:13) says, "The noblest of you in the sight of God is the best of you in conduct." The difference of IWE from the work ethics of other faiths is in the encouragement of fair and just competition, in means and in ends, as Allah says in the Quran (2:188), "Do not swallow up your property among yourselves by wrongful means" whether employees, sellers, buyers, competitors or customers, all must engage in moral and ethical conducts with good intentions and deeds, especially in dealing with business activities. 
The four concepts mentioned are the pillars of IWE from which the IWE scale was based upon. Despite this, most research on IWE scarcely measure the four concepts separately or examine how each of the four concepts influence individual's practice of IWE independently, instead IWE was usually studied as a single concept. The present study aims to predict the five personality traits against each of the four dimensions of IWE (i.e., effort, competition, transparent, and morally responsible conduct).

\section{IWE and Its Relationship with Personality Traits}

\section{Personality traits and competition in IWE}

Individuals who are high on IWE would view dedication to work as a virtue and laziness as a vice (Ali, 1992, 2005). They would consider work as a source of satisfaction, accomplishment, and self-fulfilment (Khan, Abbas, Gul, \& Raja, 2013; Nasr, 1985). Without work, individuals who are high on IWE would perceive their life as having no meaning and regard engagement in economic activities as an obligation (Khan et al., 2013). As a result, individuals with high IWE perceive cooperation or competition at work and consultation as a source of happiness and success (Khan et al., 2013). Therefore, they belong to the personality type of agreeableness and conscientiousness. Agreeableness was also mentioned to score highly on offering forgiveness and feeling happiness (Caliendo, Fossen, \& Kritikos, 2014). Since no relevant studies have been found to examine extraversion, neurotic, and openness-to-experience against each of the four dimensions of IWE, it is believed that these personality traits could influence individuals' predisposition to practise IWE in general, especially the competitive dimension. Since individuals with openness-to-experience personality perceive things as challenging, they would regard competition or cooperation as a new venture that needs to be taken on. In contrast, neurotic people would associate competition dimension of IWE negatively as they tend to be easily distracted by hurdles or problems and their emotion will affect their behaviours negatively. Meanwhile, individuals with high openness-to-experience are believed to consider jobs as a challenge. Thus, they prefer to have jobs that require high effort and hard work and see these jobs as valuable. They may also like to explore, gain experience, and be proactive in carrying out their tasks. On the contrary, extraversion employees might put more effort in their work. However, because they tend to use their mouth more than their brain, they may end up working hard but less smartly. Thus, extraversion may negatively predict the employees' predisposition towards effort dimension of IWE practices. Likewise, neuroticism also may be negatively linked to effort dimension of IWE as those high in neuroticism will tend to lose concentration at work when facing obstacles or task difficulties. Thus, these hypotheses are proposed: 
H1: Conscientiousness will be a significant positive predictor of IWE's competition dimension.

H2: Agreeableness will be a significant positive predictor of IWE's competition dimension.

H3: Extraversion will be a significant negative predictor of IWE's competition dimension.

H4: Openness-to-experience will be a significant positive predictor of IWE's competition dimension.

H5: Emotional instability will be a significant negative predictor of IWE's competition dimension.

\section{Personality traits and effort in IWE}

According to Wahab (2014), individuals who highly support the IWE are greatly affected by Islamic teachings that emphasise loyalty, hard work, and human dignity, among other traits. This is specifically indicated in the Quran (53:39) which mentions, "man has nothing except that for which he strives." According to Yousef (2001), hard work was highly encouraged in Islam, while laziness and wasting time by remaining idle or engaging in unproductive activities are greatly discouraged. Individuals with high IWE associations normally view work as a virtue and a necessity to maintain equilibrium in one's personal and social life (Khan et al., 2013). Among the characteristics of conscientiousness are hardworking, trustworthy, and honest. These are also values prescribed by Islam and the foundation of IWE. Therefore, conscientiousness can be said to link positively with IWE, while openness-to-experience characterised by philosophical and intellectual, among others, may have a tendency to explore and seek knowledge in a sincere way, and therefore willing to put more effort to achieve success. In other words, opennessto-experience can be instrumental to positively predict IWE's effort dimension. In addition, agreeableness has also been found to relate positively to ethics such as in Aghababaei et al. (2015); thus, this could predict individuals' predisposition towards effort dimension of IWE. Agreeable people dislike conflicts and want to be liked by others. They also prefer to follow instructions; hence, agreeableness may link positively with IWE's effort dimension. Thus, the following hypotheses are formulated:

H6: Conscientiousness will be a significant positive predictor of IWE's effort dimension. 
H7: Agreeableness will be a significant positive predictor of IWE's effort dimension.

H8: Extraversion will be a significant negative predictor of IWE's effort dimension.

H9: Openness-to-experience will be a significant positive predictor of IWE's effort dimension.

H10: Emotional instability will be a significant negative predictor of IWE's effort dimension.

\section{Personality traits and transparency in IWE}

According to Kristjánsson (2012), people with high openness-to-experience possess characteristics such as courage, wisdom, and justice. These are predictors of moral virtue. Islam also encourages these characteristics. Al-Ghazali indicated that courage gives rise to many virtues such as nobility, affection, endurance, and many other praiseworthy qualities. However, when there is an imbalance of courage, whether excess or shortage of it, many vices such as pride, conceit, arrogance, cowardice or meanness are created (Akhir, 2010). Therefore, individuals lacking in openness-to-experience will tend to have high emotional instability as they are unable to channel their emotion rightly. Neuroticism individuals also tend to involve themselves in unethical tendencies such as dishonest, sarcastic, and conceit because of the instability of their emotion. The Quran clearly prohibits dishonesty in any activities, whether in business dealings or in everyday activities (Elamin \& Tlaiss, 2015). Justice is also associated with Islam as Allah says in the Quran (5:8) "Be just! For justice is nearest to piety." Thus, high openness-to-experience may be coherent with IWE predisposition of transparency dimension, but negatively related with emotional instability. Likewise, individuals with conscientiousness and agreeableness traits seek to follow the ethical and work values outlined by the organisation. They tend to be trustworthy, less easily corrupted by others, and can maintain a high consideration for duties and responsibilities. Therefore, the following hypotheses are proposed:

H11: Conscientiousness will be a significant positive predictor of IWE's transparency dimension.

H12: Agreeableness will be a significant positive predictor of IWE's transparency dimension.

H13: Extraversion will be a significant negative predictor of IWE's transparency dimension. 
H14: Openness-to-experience will be a significant positive predictor of IWE's transparency dimension.

H15: Emotional instability will be a significant negative predictor of IWE's transparency dimension.

\section{Personality traits and morally responsible conduct in IWE}

In Islam, ethics have two dimensions; first, ethics towards Allah, the creator and second, ethics towards others (Abuznaid, 2009). Individuals who have high IWE's predisposition will believe in Allah and worship Him and will deal ethically with others by maintaining good relationship with them. A Muslim must adhere to the Islamic code of ethics. Thus, his or her work activities and decisions are guided by faith (iman), which is based on shariah law. This includes engaging in what is permitted (halal) and avoiding what is forbidden (haram) (Alawneh, 1998). A Muslim also has to distinguish between ethical (halal) and unethical (haram), fair and unfair, and good intention and bad intention (Abuznaid, 2009). Thus, a well-adjusted and emotional stable person in Islam experiences tawhid, obeys Allah's commands and fulfils the responsibilities assigned to him or her at work (Smither \& Khorsandi, 2009). Islamic ethics also addresses the concept of goodness (khayr), righteousness (birr), equity (qist), justice ( $a d l)$, truth (haqiqah), known and approved (ma'ruf), and piety (taqwa). Muslims, like other religious followers bring specific personality and behavioural traits to their jobs (Abuznaid, 2009; Beekun, 2004). Therefore, some Muslims may abide by the code of Islamic ethics and some may show indifference. Muslims who have high associations with IWE are expected to show high conscientiousness and agreeableness personalities, low emotional instability, and partially extraversion and openness-to-experience compared with individuals who are low in IWE. Regarding these relationships, the following hypotheses are formulated:

H16: Conscientiousness will be a significant positive predictor of IWE's morally responsible conduct dimension.

H17: Agreeableness will be a significant positive predictor of IWE's morally responsible conduct dimension.

H18: Extraversion will be a significant negative predictor of IWE's morally responsible conduct dimension.

H19: Openness-to-experience will be a significant positive predictor of IWE's morally responsible conduct dimension. 
H20: Emotional instability will be a significant negative predictor of IWE's morally responsible conduct dimension.

\section{METHOD}

A quantitative research methodology was used in this study to test the proposition that employees' predisposition towards IWE could be predicted based on their personality traits. The study aims to test whether the personality traits are good predictors of employees' IWE. Therefore, only Muslim employees were sampled as they are believed to have higher associations with IWE than the non-Muslim employees. This study utilised Gpower software to arrive at the minimum sample size required. The sample size needed for five independent variables and four dependent variables using effect size $\left(f^{2}\right)$ of 0.12 is 160 respondents. Several organisations across different industries were contacted to get their approval for distributing the questionnaires to their employees. The distribution and the collection of the questionnaires were conducted upon approval from the related organisations. In general, this study used random and convenient sampling of employees working in various industries ranging from banking and finance institutions, government departments, and hospitals. Data were collected through survey questionnaires. Of the total of 250 survey questionnaires circulated, 182 were usable; thus, the final response rate stood at $72.80 \%$.

Smart PLS 3.2 software was used to assess the predictive relationship between personality traits and IWE. The study used two-stage analytical procedures involving measurement model (validity and reliability) and structural model (Anderson \& Gerbing, 1988). In the structural model, boot strapping method was used to test the significant path coefficient and loadings (Hair, Hult, Ringle, \& Sarstedt, 2016).

\section{Measures}

\section{Personality factors}

The personality factors were measured using Goldberg (1990) which comprises 36 measurement instruments. Each item was rated on a 5-point Likert scale ranging from $1=$ strongly disagree to $5=$ strongly agree. Example of items for personality factors include: "I talk to a lot of different people at social functions" (extraversion), "I sympathise with others' feeling" (agreeableness), "I like order" (conscientiousness), "I see myself as someone who is curious about many different things" (openness-to-experience), and "I often feel depress" (neuroticism). The 
Cronbach alpha in previous study for these measures were 0.78 for extraversion, 0.71 for agreeableness, 0.76 for conscientiousness, 0.83 for emotional stability, and 0.77 for openness-to-experience (Karim et al., 2009).

\section{IWE}

IWE factors were measured using Ali's (2005) short version of the IWE scale. The IWE scale consisted of 17 items, and each of the items was tested on a 5-point Likert scale format ranging from $1=$ strongly disagree to $5=$ strongly agree. This scale was the most widely used scale available to measure the IWE (Ali \& Azim, 1994). Examples of items for IWE include "Dedication to work is a virtue" and "Work enables man to control nature." The reliability $(\alpha)$ for this instrument was 0.84 .

\section{Control variable}

Religion was treated as a control variable. Only Muslim respondents were selected because the objective of this study is to examine whether the individuals' IWE predisposition could be predicted from their personality traits. Since IWE are highly positively associated with Muslims compared with other religious beliefs, thus, Muslims are perceived as more relevant to be sampled for this study. Therefore, only data from Muslims respondents were run for the analysis and data from nonMuslims were excluded.

\section{Data Analysis and Result}

\section{Common method bias}

This study used self-report questionnaire data from the same source for both personality traits and IWE. Therefore, the possibility of having a common method bias (CMB) cannot be overruled. According to Podsakoff, MacKenzie, Lee, and Podsakoff (2003), CMB can be detected through Harman Single Factor test by running a simple and unrotated factor analysis with eigenvalue greater than one. The results of factor analysis using unrotated Principle Component Analysis (PCA) in this study revealed that nine distinct factors accounted for $65.2 \%$ of the percentage of total variance with the first factor capturing only $20.83 \%$ of the whole variance in the data. The results indicated that the data of this study produced a number of factors. The first factor retained less than $50 \%$ of the total variance; therefore, $\mathrm{CMB}$ is not a significant issue in the data. 


\section{Exploratory factor analysis}

The study conducted exploratory factor analysis (EFA) to verify whether IWE is a single factor or otherwise, before embarking on testing the various relationships. Ali (2005), the author who inaugurated the IWE scale indicated that IWE was built on four primary concepts, namely effort, competition, transparency, and morally responsible conduct. However, till to date, the IWE in most previous studies were tested as one composite dimension. In this study, the 17 items of IWE were factor analysed and the result has generated four dimensions. Of this, only three indicated clean factors and one was double-loaded factor. Table 1 displays the result of factor analysis using PCA with Varimax rotations.

Table 1

EFA of IWE factors

\begin{tabular}{cc}
\hline Items & Factor loadings \\
\hline
\end{tabular}

Effort $(\alpha=\mathbf{0 . 8 5 7})$

1. Laziness is a vice.

2. Dedication to work is a virtue.

3. Good work benefits both one's self and others.

4. Producing more than enough to meet one's needs contributes to the prosperity of society as a whole.

5. More leisure time is good for society.

6. Justice and generosity in the work place are necessary conditions for society's welfare.

7. One should carry work out to the best of one's ability.

Competition $(\alpha=0.803)$

1. Creative work is a source of happiness and accomplishment.

2. Work enables man to control nature.

0.734

3. Work is not an end in itself but a means to foster personal growth and social relations.

4. Human relations should be emphasised and encouraged.

5. Any person who works is more likely to get ahead in life.

Transparency $(\alpha=0.765)$

1. One should constantly work hard to meet responsibilities.

2. The value of work is delivered from the accompanying intention rather than its result.

3. Work gives one the chance to be independent.

4. A successful person is the one who meets deadlines at work. 
The result of EFA indicated that three clean dimensions of IWE have been generated for this data with percentage total variance of $60.48 \%$. This means that only 15 out of 20 formulated hypotheses will be tested (i.e., H1 to H15) in further analysis of the study and 5 have to be discarded. Hence, the theoretical framework was revised and is displayed in Figure 1.

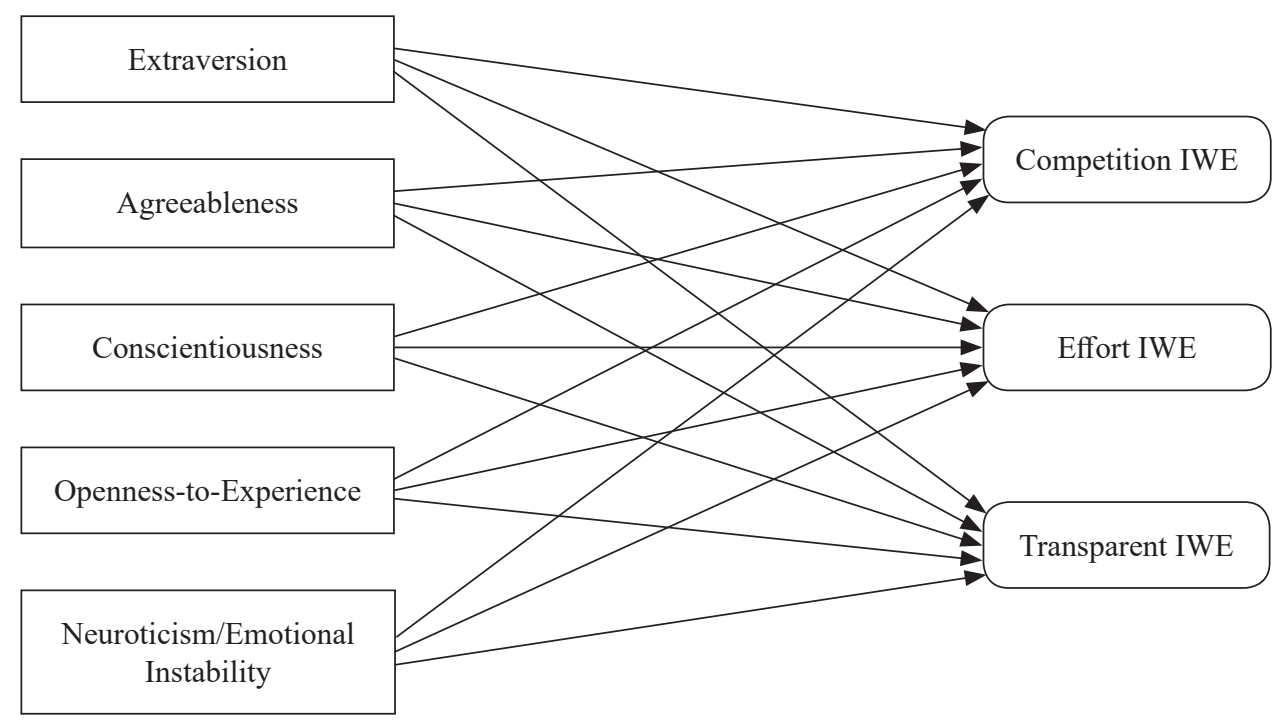

Figure 1. The revised conceptual framework on the nexus between personality traits and IWE

\section{Participants}

The respondents in this study were all Muslims (100\%) with $76(43.4 \%)$ males and $99(54.4 \%)$ females. Their age ranged from 24 and below (23.6\%) to above 61 years old $(0.5 \%)$ with the majority were from 31 to 40 years old (35.7\%). Of this, 179 (98.4\%) were Malays and one was Chinese $(0.5 \%)$, and two $(1.1 \%)$ were of other ethnicity. The majority has 1 to 3 years working experience $(44.4 \%)$ followed by 4 to 7 years (21.4\%) and 8 to 10 years of experience (16.5\%). In terms of educational level, the majority has a diploma (67.4\%) followed by a bachelor degree (17.7\%). 


\section{RESULTS}

\section{Measurement Model}

\section{Convergent validity}

Convergent validity and average variance extracted (AVE) are two important tests to determine the validity and reliability of the items as recommended by Fornell and Larcker (1981). As a condition for the construct to have good convergent reliability, the items for personality traits and IWE used must fulfil the minimum requirement of 0.5 for factor loadings, 0.7 for composite reliability (Hair, Ringle, \& Sarstedt, 2011) and Cronbach alpha respectively (Gefen, Straub, \& Bordeau, 2000 ) as this value indicates adequate internal consistency, 0.5 for AVE (Bagozzi $\& \mathrm{Yi}, 1988$ ) as it explains more than $50 \%$ of the construct's variance (Hair et al., 2016). Discriminant validity was also tested to ensure that the constructs under study are distinctive from each other and not measuring the same thing.

The result of Cronbach's alpha $(\alpha)$, composite reliability (CR), and AVE of the construct of the study exhibited values greater than the recommended values with $\alpha$ and CR values for all constructs are above 0.7, and AVE values are all above 0.5. Therefore, all constructs in this study fulfil the requirement for convergent validity. Table 2 shows the results of convergent validity of the study for the measurement model.

Table 2

Results of convergent validity

\begin{tabular}{lccc}
\hline Constructs & $\alpha$ & CR & AVE \\
\hline Competitive IWE & 0.82 & 0.88 & 0.65 \\
Effort IWE & 0.85 & 0.89 & 0.63 \\
Transparent IWE & 0.80 & 0.87 & 0.62 \\
Conscientiousness & 0.80 & 0.89 & 0.72 \\
Extraversion & 0.86 & 0.89 & 0.58 \\
Neuroticism/emotional instability & 0.94 & 0.95 & 0.69 \\
Openness-to-experience & 0.57 & 0.82 & 0.70 \\
Agreeableness & 0.75 & 0.88 & 0.79 \\
\hline
\end{tabular}




\section{Discriminant Validity}

Discriminant validity of each construct can be determined by comparing the square root of AVE with the correlation between the constructs (Fornell \& Larcker, 1981). The constructs can be said to have discriminant validity if the square root of AVEs exhibit greater values than the correlation values of all the constructs. Discriminant validity was run and the results showed that the square root of AVEs were greater than the correlation of all the constructs. Thus, the measurement model of the study satisfied the requirement of the discriminant validity test. The results are illustrated in Table 3.

Table 3

Results of discriminant validity (Fornell and Larckel criterion)

\begin{tabular}{lcccccccc}
\hline Constructs & 1 & 2 & 3 & 4 & 5 & 6 & 7 & 8 \\
\hline Agreeableness & $\mathbf{0 . 8 9}$ & & & & & & & \\
Competitive IWE & 0.21 & $\mathbf{0 . 8 0}$ & & & & & & \\
Conscientiousness & 0.31 & 0.12 & $\mathbf{0 . 8 5}$ & & & & & \\
Effort IWE & 0.30 & 0.54 & 0.30 & $\mathbf{0 . 7 9}$ & & & & \\
Neuroticism & 0.20 & 0.20 & 0.39 & 0.27 & $\mathbf{0 . 7 6}$ & & & \\
Extraversion & 0.13 & 0.02 & -0.21 & -0.21 & -0.26 & $\mathbf{0 . 8 3}$ & & \\
Openness-to-experience & 0.38 & 0.36 & 0.36 & 0.47 & 0.28 & -0.09 & $\mathbf{0 . 8 4}$ & \\
Transparent IWE & 0.31 & 0.57 & 0.19 & 0.38 & 0.14 & -0.05 & 0.25 & $\mathbf{0 . 7 9}$ \\
\hline
\end{tabular}

Note: The bold values (diagonal) represent the square root of AVE values

\section{Structural Model}

\section{Variance inflation factor for multicollinearity test}

The variance inflation factor (VIF) was also analysed prior to testing the path coefficient to ensure the constructs are free from collinearity issues. Neter, Wasserman, and Kutner (1990) suggested the requirement that VIF should be below 5 in order to be free from multicollinearity problems. Multicollinearity will reduce the discriminant validity of the construct, thus, reducing the quality of the study as it will reduce the generalisability of the study to other contexts. The results indicated that all the constructs have VIF statistics below 5, which is within the threshold recommended. Thus, multicollinearity is not a major issue in this study. The VIF results of the study are exhibited in Table 4. 
Table 4

Results of multicollinearity test

\begin{tabular}{lc}
\hline Constructs & VIF \\
\hline Agreeableness & 1.30 \\
Conscientiousness & 1.37 \\
Neuroticism & 1.16 \\
Extraversion & 1.28 \\
Openness-to-experience & 1.30 \\
\hline
\end{tabular}

\section{Fit statistics}

In the structural model, goodness of fit (GoF) was assessed to estimate the strength of predictive dependent (exogenous) variables that can be explained by independent (endogenous) variables. Akter, D'Ambra, and Ray (2011) set GoF of 0.1 as small, above 0.25 as moderate and above 0.36 as excellent. The minimum for GoF is 0.25 as a baseline for using Smart PLS statistical tools. Another fit statistics is Stone-Geisser's predictive relevance $\left(Q^{2}\right)$ and coefficient of determination $\left(R^{2}\right)$. $Q^{2}$ test is the predictive relevance measures of the endogenous variable. In other words, $Q^{2}$ measures to what extent the prediction is successful. If $Q^{2}$ values of the dependent variables are greater than 0 , then they imply that the model has predictive relevance. The result showed that the GoF of this study was 0.67 , thus it is considered as an excellent level of GoF. All IWE's dimensions indicated a satisfactory $Q^{2}$ value. Competition, effort, and transparency dimensions of IWE showed acceptable result of $Q^{2}$ larger than zero $(0.08,0.16$, and 0.05$)$, and $R^{2}$ $(0.15,0.29$, and 0.12$)$ accordingly. $R^{2}$ indicated that the exogenous variables (i.e., personality traits) explain $15 \%$ of competition dimension, $29 \%$ of effort dimension, and $12 \%$ of transparency dimension of IWE. Table 5 displays the results of $Q^{2}$ and $R^{2}$.

Table 5

Results of model fit

\begin{tabular}{lcc}
\hline Constructs & $R^{2}$ & $Q^{2}$ \\
\hline Competitive IWE & 0.15 & 0.08 \\
Effort IWE & 0.29 & 0.16 \\
Transparent IWE & 0.12 & 0.05 \\
\hline
\end{tabular}

Note: $\mathrm{GoF}=0.67$ 


\section{Path coefficient}

A non-parametric bootstrapping procedure with 500 resample and 182 cases was used to assess the significance of path coefficient. The results exhibited that only 5 hypotheses were supported and 10 were not. The main findings showed that only openness-to-experience personality could significantly and positively predict competition and effort dimensions of IWE. Agreeableness personality trait could only predict the effort and transparent dimensions. On the other hand, emotional instability was significantly found to negatively predict IWE of effort dimension. The path diagram and the relationship between all endogenous and exogenous variables of the study are shown in Figure 2, while the results of path coefficient are displayed in Table 6.

Table 6

Results of path coefficients of the study

\begin{tabular}{llrllll}
\hline Hypo & Relationship & Beta & SE & $\begin{array}{c}\text { T-Stats } \\
(\mathrm{p}>1.65)\end{array}$ & P-values & Result \\
\hline H1 & Conscientiousness $\rightarrow$ Competitive IWE & -0.04 & 0.10 & 0.40 & 0.69 & Not supported \\
H2 & Agreeableness $\rightarrow$ Competitive IWE & 0.03 & 0.10 & 0.33 & 0.74 & Not supported \\
H3 & Extraversion $\rightarrow$ Competitive IWE & 0.13 & 0.10 & 1.26 & 0.21 & Not supported \\
H4 & OTE $\rightarrow$ Competitive IWE & 0.31 & 0.09 & $3.51^{* *}$ & 0.00 & Supported \\
H5 & Neuroticism $\rightarrow$ Competitive IWE & 0.10 & 0.11 & 0.90 & 0.37 & Not supported \\
H6 & Conscientiousness $\rightarrow$ Effort IWE & 0.04 & 0.09 & 0.46 & 0.65 & Not supported \\
H7 & Agreeableness $\rightarrow$ Effort IWE & 0.13 & 0.08 & $1.73^{*}$ & 0.08 & Supported \\
H8 & Extraversion $\rightarrow$ Effort IWE & 0.04 & 0.09 & 0.51 & 0.61 & Not supported \\
H9 & OTE $\rightarrow$ Effort IWE & 0.34 & 0.08 & $4.33^{* *}$ & 0.00 & Supported \\
H10 & Neuroticism $\rightarrow$ Effort IWE & -0.17 & 0.08 & $2.25^{*}$ & 0.03 & Supported \\
H11 & Conscientiousness $\rightarrow$ Transparent IWE & 0.04 & 0.09 & 0.47 & 0.64 & Not supported \\
H12 & Agreeableness $\rightarrow$ Transparent IWE & 0.18 & 0.10 & $1.78^{*}$ & 0.08 & Supported \\
H13 & Extraversion $\rightarrow$ Transparent IWE & 0.01 & 0.12 & 0.06 & 0.96 & Not supported \\
H14 & OTE $\rightarrow$ Transparent IWE & 0.13 & 0.11 & 1.20 & 0.23 & Not supported \\
H15 & Neuroticism $\rightarrow$ Transparent IWE & -0.04 & 0.11 & 0.32 & 0.75 & Not supported \\
\hline
\end{tabular}

Note: OTE $=$ Openness-to-experience, $*$ significant at $0.05, * *$ significant at 0.001 


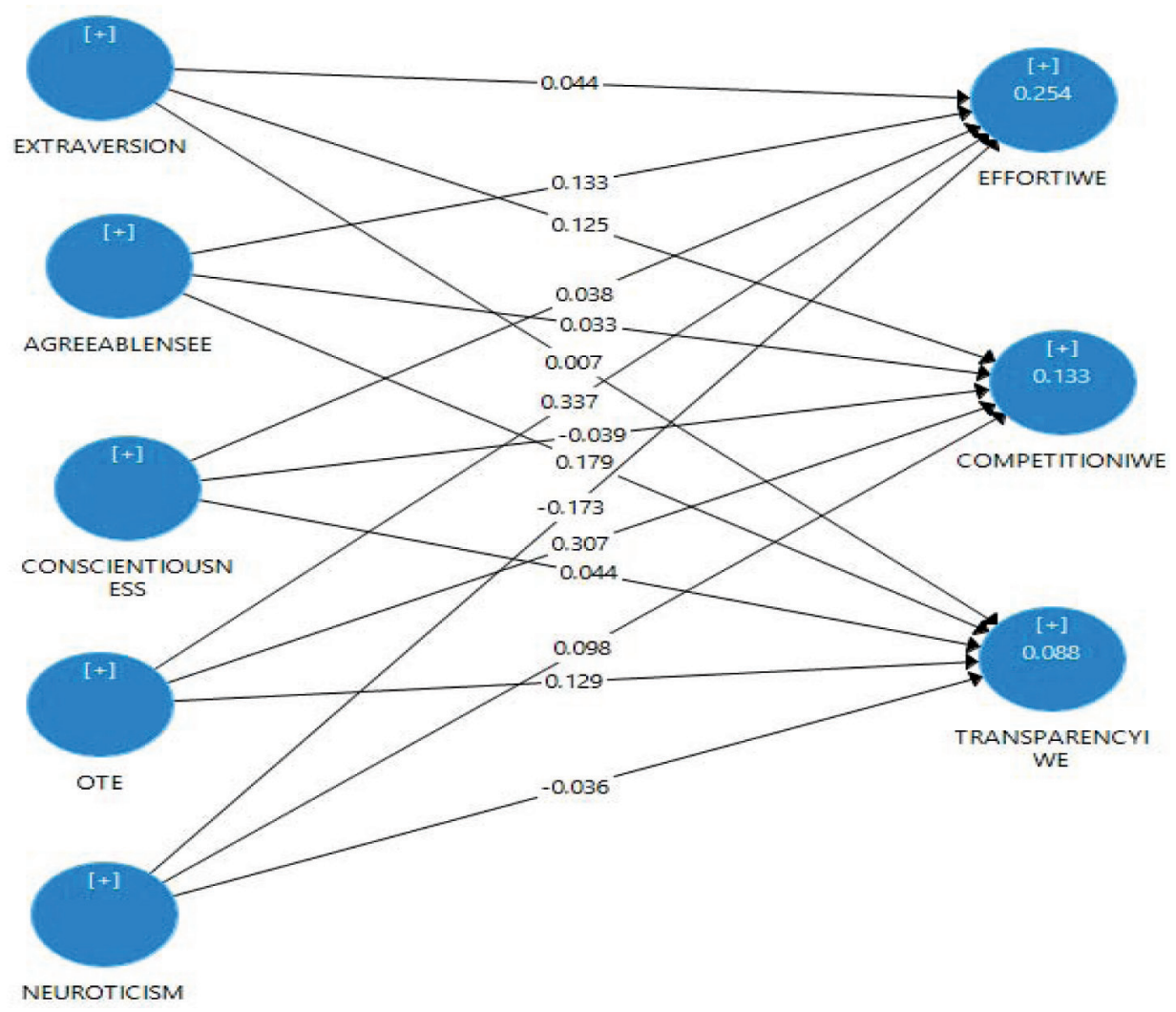

Figure 2. The relationship between endogenous and exogenous variables of the study

\section{DISCUSSION}

The findings indicated that personality traits have a moderate influence on IWE. Among personality traits, openness-to-experience, agreeableness, and emotional instability (neuroticism) of personality traits were the significant predictors of the IWE, especially the effort and competitive dimensions. In particular, openness-toexperience shows a positive significant relationship with the effort and competition dimensions of IWE. The results also indicated that agreeableness is a significant positive predictor and neuroticism or emotional instability is a negative predictor of effort in IWE. The beta value for the personality trait of emotional instability showed a negative significant relationship with the effort dimension of IWE. One possible explanation is that employees who have high IWE normally have a strong belief in the Quran and sunnah, which are the main Islamic and IWE sources. The Quran clearly outlines on how to lead a good way of life. Details about rules in economy (muamalat), ritual worship (ibadah), marriage (munakahat), and so on 
are indicated in the Quran and the sunnah. Emotional instable Muslims are those who disassociate themselves with the religion and unlikely to endorse religious ethics, thus, they behave in the opposite of IWE. According to Elkadi (1985), Quran has a healing (ruqyah) power which has an effect on the mind and spirit; and it has a direct effect on the human body. For people with emotional stability, Allah is the source of guidance, relief, protection, support, and sustenance; this helps in reducing anxiety, depression, and other kinds of emotional instabilities. This finding also is specifically consistent with those of previous studies which showed that neurotic individuals tend to have lower predisposition towards ethical behaviour (Walumbwa \& Schaubroeck, 2009). According to Kalshoven et al. (2011), neurotic individuals possess lower self-esteem and low self-efficacy, and therefore are always feeling anxious, depressed, stressed, and moody.

Openness-to-experience also was found to be a good positive predictor of effort and competition dimensions of IWE. Normally, individuals with openness-toexperience are high in intellectual ability and characterised as intelligent, creative, and insightful. Therefore, it is not surprising if these qualities are good predictors of effort and competition dimensions of IWE. Many qualities of openness-toexperience are encouraged by Islam. Among them are qualities such as courage, wisdom, and justice, which are also the opposite of unethical traits. Therefore, openness-to-experience, as expected, was found to positively predict IWE (effort dimension). This finding is considered a significant contribution of this study as most research that have tested the relationship between personality traits and ethics have excluded openness-to-experience trait in their equations.

The findings also indicated that agreeableness is a good predictor of IWE pertaining to effort. This is because people with agreeableness are cooperative and dislike conflicts, they can easily be misguided, especially if their religious and ethical values are not strong. Their nature of kindness, considerate, warm, and caring would normally make agreeableness individuals conform to the universalities. For example, if the majority of the employees in an organisation are in favour of ethical disposition, they likewise will be cooperative and accommodative. Individuals high on agreeableness are also bound to be fearful. For example, they fear of being punished, thus, they tend to comply with laws and regulations, and this makes them honest, decent and trustworthy individuals. However, their loyalty can be steered if no penalty is applied for not sticking to the law. Agreeableness employees with strong religious and ethical beliefs normally abide by the rules. This may explain why agreeableness personality was found to be a good predictor of effort dimension in IWE, not in the competition dimension. Individuals high in agreeableness possess a strong trait of cooperativeness, thus, they are likely to comply with the Islamic teachings by working hard and putting effort, instead of 
competing. This can also be a possible reason why agreeableness was found to link closely with effort dimension and less with competition dimension of IWE.

In contrast, conscientiousness and extraversion were found not to have significant predictive relationships with IWE as has been hypothesised. Conscientious personality is supposed to relate significantly to effort and competition dimensions of IWE as both have hardworking, dutiful, and responsible characteristics. However, the findings did not indicate a significant relationship. Therefore, conscientiousness and extraversion are not significant predictors of IWE.

\section{CONCLUDING REMARKS AND IMPLICATIONS}

Despite receiving much attention from many researchers, personality traits have been less researched with regard to religious work ethic. The present study aims to use the powerful tool of prediction of personality traits in constructing a link with the IWE. Employees rated high on the IWE are believed to have lower neurotic tendency of feeling depressed, stressed, and moody. This is perhaps due to the role of Quran and sunnah as the sources of IWE, which contain teachings related to personal behaviours and attitudes that guide individuals in conducting their daily life. Furthermore, IWE also contains teachings of general goals such as freedom, justice, and improved economic condition that can lead to balanced, stable, and emotionally successful individuals (Elkadi, 1985). This will lead employees to feel more satisfied with their jobs and their organisational commitment will increase.

Muslim employees who are high on openness-to-experience may have their results interpreted differently in the West. As openness-to-experience are unconventionality people characterised by imaginative, autonomous, and nonconforming behaviours (Judge et al., 1999). Therefore, individuals high in openness-to-experience personality may get involved in unethical activities if these behaviours could satisfy their needs to explore, change, and challenge. However, if they have strong religious and ethical values such as that of IWE, these values could guide their openness-to-experience traits to move towards ethical predisposition if and only their religious and ethical values are strong. Islam can have a significant effect on people's personality traits; it can guide and correct individuals' immoral inclinations if their religious adoption and practices are well built. On the other hand, agreeableness personality possesses characteristics that are likeable and soft heartedness. These characteristics are closely linked to good morale and work ethics as Islam also prohibits provocations, aggressions, and conflicts, thus, encourages Muslims to have agreeableness personality to have a good, strong, and united society (ummah). 
The findings of this study can provide useful insights to organisations regarding the role of openness-to-experience, agreeableness, and emotional instability of personality traits in predicting IWE. The managers may be interested to know what kind of employees could be trusted when dealing with ethical projects involving high work ethics, transparency, or integrity. The managers may also now have evidence supported by the research of how to select employees based on the personality traits when dealing with ethical, sustainable, morally responsible, or environmentally sensitive projects to have higher chances of success, given that the association between personality traits and work ethic have been established. Another implication of this study is that these findings will help human resource management predict their employees' work ethic by using the already established and well-accepted test of personality traits. This finding also may be useful for human resource management and managers to consider when dealing with ethical issues. Individuals low in neuroticism also should be a concern as they might have a higher tendency to involve in unethical proclivity. However, personality traits should not be used as a single factor when determining the employees' predisposition that may or may not involve them in unethical behaviours. Other tests also should be used to complement the personality traits to arrive at a more accurate decision for the fear that it will raise many bias or discrimination issues.

\section{ACKNOWLEDGEMENT}

The author would like to thank Universiti Sains Malaysia for funding this project under the Short-Term Research Grant Scheme No. 304/PMGT/6313150.

\section{REFERENCES}

Abuznaid, S.A. (2009). Business ethics in Islam: The glaring gap in practice. International Journal of Islamic Middle Eastern Finance and Management, 2(4), 278- 288. https://doi.org/10.1108/17538390911006340

Achour, M., Nor, M.R.M., \& Mohd Yusoff, M.Y.Z. (2016). Islamic personal religiosity as a moderator of job strain and employee's well-being: The case of Malaysian academic and administrative staff. Journal of Religion and Health, 55(4), 13001311. https://doi.org/10.1007/s10943-015-0050-5

Aghababaei, N. (2013). Between you and God, where is the general factor of personality? Exploring personality-religion relationships in a Muslim context. Personality and Individual Differences, 55(2), 196-198. https://doi.org/10.1016/j. paid.2013.02.021 
Aghababaei, N., Błachnio, A., Arji, A., Chiniforoushan, M., Tekke, M., \& Mehrabadi, A.F. (2015). Honesty-humility and the HEXACO structure of religiosity and wellbeing. Current Psychology, 35(3), 421-426.

Akhir, N.S.M. (2010). Al-Ghazali and his theory of the soul: A comparative study. Pulau Pinang: Penerbit Universiti Sains Malaysia.

Akter, S., D'Ambra, J., \& Ray, P. (2011). An evaluation of PLS based complex models: The roles of power analysis, predictive relevance and GoF index. In AMCIS 2011 Proceedings. Detroit, Michigan: Association for Information System AIS Electronic Library (AISeL). Retrieved 7 January 2017 from http://aisel.aisnet.org/ cgi/viewcontent.cgi?article=1091\&amp; context=amcis2011_submissions

Alawneh, S.F. (1998). Human motivation: An Islamic perspective. American Journal of Islamic Social Sciences, 15(4), 19-39.

Al-Misri, S.M. (2013). La tahzan wabtasim li al-hayah. Cairo: Maktabah al-Safa.

Ali, A. (1992). The Islamic work ethic in Arabia. The Journal of Psychology, 126(5), 507519. https://doi.org/10.1080/00223980.1992.10543384

Ali, A., \& Azim, A. (1994). Islamic work ethic and organization in development. Paper presented at the 23rd International Congress of Applied Psychology, Madrid, Spain.

Ali, A.J., \& Al-Owaihan, A. (2008). Islamic work ethic: A critical review. Cross Cultural Management: An International Journal, 15(1), 5-19. https://doi. org/10.1108/13527600810848791

Ali, J.A. (2005). Islamic perspectives on management and organization. UK: Edward Elgar Publishing.

Anas, E., \& Mounira, B.A. (2009). Ethical investment and the social responsibilities of the Islamic banks. International Business Research, 2(2), 123-130. https://doi. org/10.5539/ibr.v2n2p123

Anderson, J.C., \& Gerbing, D.W. (1988). Structural equation modeling in practice: A review and recommended two-step approach. Psychological Bulletin, 103(3), 411-423. https://doi.org/10.1037/0033-2909.103.3.411

Andreassen, C.S., Hetland, J., \& Pallesen, S. (2010). The relationship between 'workaholism', basic needs satisfaction at work and personality. European Journal of Personality, 24(1), 3-17. https://doi.org/10.1002/per.737

Bagozzi, R.P., \& Yi, Y. (1988). On the evaluation of structural equation models. Journal of the Academy of Marketing Science, 16(1), 74-94. https://doi.org/10.1007/ BF02723327

Barrett, L.F., \& Pietromonaco, P.R. (1997). Accuracy of the five-factor model in predicting perceptions of daily social interactions. Personality and Social Psychology Bulletin, 23(1), 1173-1187. https://doi.org/10.1177/01461672972311005

Beekun, R.I. (2004). Islamic business ethics. New Delhi: Goodword Books Pvt.

Bratton, V.K., \& Strittmatter, C. (2013). To cheat or not to cheat? The role of personality in academic and business ethics. Ethics \& Behavior, 23(6), 427-444. https://doi. org/10.1080/10508422.2013.811077

Brown, M.E., \& Treviño, L.K. (2006). Ethical leadership: A review and future directions. The Leadership Quarterly, 17(6), 595-616. https://doi.org/10.1016/j. leaqua.2006.10.004 
Caliendo, M., Fossen, F., \& Kritikos, A.S. (2014). Personality characteristics and the decisions to become and stay self-employed. Small Business Economics, 42(4), 787-814. https://doi.org/10.1007/s11187-013-9514-8

Camps, J., Stouten, J., \& Euwema, M. (2016). The relation between supervisors' big five personality traits and employees' experiences of abusive supervision. Frontiers in Psychology, 7(112), 1-11. https://doi.org/10.3389/fpsyg.2016.00112

Cooper, D.A., Slaughter, J., \& Gilliland, S. (2014). Good apples in good barrels: Ethical code enforcement, conscientiousness, and unethical behavior. In Academy of Management Proceedings (Meeting Abstract Supplement, vol. 1, p. 12658). New York: Academy of Management.

Cubel, M., Nuevo-Chiquero, A., Sanchez-Pages, S., \& Vidal-Fernandez, M. (2016). Do personality traits affect productivity? Evidence from the laboratory. The Economic Journal, 126(592), 654-681. https://doi.org/10.1111/ecoj.12373

Elamin, A.M., \& Tlaiss, H.A. (2015). Exploring the relationship between organizational citizenship behavior and organizational justice in the Islamic Saudi Arabian context. Employee Relations, 37(1), 2-29. https://oi.org/10.1108/ER-03-20140033

Elkadi, A. (1985). Health and healing in the Qur'an: Towards an understanding of the healing effect of the Qur'an. Paper submitted for presentation at the 18th Annual Convention of Islamic Medical Association of North America, Niagara Fall, NY.

Fornell, C., \& Larcker, D.F. (1981). Structural equation models with unobservable variables and measurement error: Algebra and statistics. Journal of Marketing Research, 18(3), 382-388. https://doi.org/10.2307/3150980

Francis, L.J. (1992). Is psychoticism really a dimension of personality fundamental to religiosity? Personality and Individual Differences, 13(6), 645-652. https://doi. org/10.1016/0191-8869(92)90235-H

Gefen, D., Straub, D.W., \& Bordeau, M.C. (2000). Structural equation modelling and regression: Guidelines for research practice. Communications of the Association for Information Systems, 4(7), 1-79.

Goldberg, L.R. (1990). An alternative" description of personality": The big-five factor structure. Journal of Personality and Social Psychology, 59(6), 1216-1229. https://doi.org/10.1037/0022-3514.59.6.1216

Gosling, S.D., Rentfrow, P.J., \& Swann Jr, W.B. (2003). A very brief measure of the bigfive personality domains. Journal of Research in Personality, 37(6), 504-528. https://doi.org/10.1016/S0092-6566(03)00046-1

Greenbaum, R.L., Hill, A., Mawritz, M.B., \& Quade, M.J. (2014). Employee machiavellianism to unethical behaviour: The role of abusive supervision as a trait activator. Journal of Management, 43(2), 585-609. https://doi. org/10.1177/0149206314535434

Hair Jr., J.F., Hult, G.T.M., Ringle, C., \& Sarstedt, M. (2016). A primer on partial least squares structural equation modeling (PLS-SEM). USA: Sage Publications.

Hair, J.F., Ringle, C.M., \& Sarstedt, M. (2011). PLS-SEM: Indeed a silver bullet. Journal of Marketing Theory and Practice, 19(2), 139-152. https://doi.org/10.2753/ MTP1069-6679190202 
Hassan, N.M.N. (2002). Business social responsibility from the Islamic perspective. In N.M.N. Hassan \& S.M.S.S.M. Salleh (Eds.), Corporate governance from the Islamic perspective (pp. 25-41). Kuala Lumpur: Institute of Islamic Understanding Malaysia (IKIM).

Hong, R.Y., Koh, S., \& Paunonen, S.V. (2012). Supernumerary personality traits beyond the big five: Predicting materialism and unethical behavior. Personality and Individual Differences, 53, 710-715. https://doi.org/10.1016/j.paid.2012.05.030

Javed, M.K., Nazam, M., Ahmad, J., \& Nadeem, A.H. (2014). The impact of consumer perceived ethical value on trust and brand loyalty: Personality as moderation variable. In Proceedings of the Eighth International Conference on Management Science and Engineering Management (pp. 1585-1594). Berlin-Heidelberg: Springer. https://doi.org/10.1007/978-3-642-55122-2_137

Johnstone, B., Yoon, D.P., Cohen, D., Schopp, L.H., McCormack, G., Campbell, J., \& Smith, M. (2012). Relationships among spirituality, religious practices, personality factors, and health for five different faith traditions. Journal of Religion and Health, 51(4), 1017-1041. https://doi.org/10.1007/s10943-012-9615-8

Judge, T.A., Higgins, C.A., Thoresen, C.J., \& Barrick, M.R. (1999). The big five personality traits, general mental ability, and career success across the life span. Personnel Psychology, 52, 621-652. https://doi.org/10.1111/j.1744-6570.1999.tb00174.x

Kalshoven, K., Den Hartog, D.N., \& De Hoogh, A.H. (2011). Ethical leader behaviour and big five factors of personality. Journal of Business Ethics, 100(2), 349-366. https://doi.org/10.1007/s10551-010-0685-9

Karim, N.S.A., Zamzuri, N.H.A., \& Nor, Y.M. (2009). Exploring the relationship between internet ethics in university students and the big five model of personality. Computers \& Education, 53(1), 86-93. https://doi.org/10.1016/j. compedu.2009.01.001

Khan, A.M., Nazeer, S.U., \& Naqvi, S.M.I.H. (2015). Personality mediated career development under Islamic work ethics in Pakistani religious schools. European Online Journal of Natural and Social Sciences, 4(4), 691-703.

Khan, K., Abbas, M., Gul, A., \& Raja, U. (2013). Organizational justice and job outcomes: Moderating role of Islamic work ethic. Journal of Business Ethics, 126(2), 235246. https://doi.org/10.1007/s10551-013-1937-2

Kristjánsson, K. (2012). Selfhood, morality, and the five-factor model of personality. Theory \& Psychology, 22(5), 591-606. https://doi.org/10.1177/0959354311431193

McFerran, B., Aquino, K., \& Duffy, M. (2010). How personality and moral identity relate to individuals' ethical ideology. Business Ethics Quarterly, 20(1), 35-56. https://doi.org/10.5840/beq20102014

Motowidlo, S.J., Ghosh, K., Mendoza, A.M., Buchanan, A.E., \& Lerma, M.N., (2016). A context-independent situational judgment test to measure prosocial implicit trait policy. Human Performance, 29(4), 331-346. https://doi.org/10.1080/08959285. 2016.1165227

Othman, A.K., Hamzah, M.I., \& Hashim, N. (2014). Conceptualizing the Islamic personality model. Procedia-Social and Behavioral Sciences, 130, 114-119. https://doi.org/10.1016/j.sbspro.2014.04.014 
Nasr, S.H. (1985). Islamic work ethic in comparative work ethics. Occasional papers of the Council of Scholars. Washington, DC: Library of Congress.

Neter, J., Wasserman, W., \& Kutner, M.H. (1990). Applied linear statistical models: Regression, analysis of variance, and experimental designs (3rd ed.). Homewood, IL: Richard D. Irwin.

Podsakoff, P.M., MacKenzie, S.B., Lee, J.Y., \& Podsakoff, N.P. (2003). Common method biases in behavioral research: A critical review of the literature and recommended remedies. Journal of Applied Psychology, 88(5), 879-903. https://doi.org/10.1037/0021-9010.88.5.879

Park, H., Blenkinsopp, J., \& Park, M. (2014). The influence of an observer's value orientation and personality type on attitudes toward whistleblowing. Journal of Business Ethics, 120(1), 121-129. https://doi.org/10.1007/s10551-013-1908-7

Prewett, M.S., Brown, M.I., Goswami, A., \& Christiansen, N.D. (2016). Effects of team personality composition on member performance: A multilevel perspective. Group \& Organization Management (pp. 1-33). https://doi.org/ $10.1177 / 1059601116668633$

Reynolds, S.J. (2006). Moral awareness and ethical predispositions: Investigating the role of individual differences in the recognition of moral issues. Journal of Applied Psychology, 91(1), 233-243. https://doi.org/10.1037/0021-9010.91.1.233

Robinson, T.N. (1990). Eysenck personality measures and religious orientation. Personality and Individual Differences, 11(9), 915-921. https://doi.org/10.1016/01918869(90)90272-S

Quintelier, E. (2014). The influence of the big 5 personality traits on young people's political consumer behaviour. Young Consumers, 15(4), 342-352. https://doi. org/10.1108/YC-09-2013-00395

Saadullah, S.M., \& Bailey, C.D. (2014). The "big five personality traits" and accountants' ethical intention formation. Research on Professional Responsibility and Ethics in Accounting, 18, 167-191. https://doi.org/10.1108/S1574-076520140000018006

Saroglou, V. (2012). Is religion not prosocial at all? Comment on Galen. Psychological Bulletin, 138(5), 907-912. https://doi.org/10.1037/a0028927

Saroglou, V., \& Munoz-Garcia, A. (2008). Individual differences in religion and spirituality: An issue of personality traits and/or values. Journal for the Scientific Study of Religion, 47(1), 83-101. https://doi.org/10.1111/j.1468-5906.2008.00393.x

Smither, R., \& Khorsandi, A. (2009). The implicit personality theory of Islam. Psychology of Religion and Spirituality, 1(2), 81-96. https://doi.org/10.1037/a0015737

Taylor, A., \& MacDonald, D.A. (1999). Religion and the five factor model of personality: An exploratory investigation using a Canadian university sample. Personality and Individual Differences, 27(6), 1243-1259. https://doi.org/10.1016/S01918869(99)00068-9

Uddin, M., Ali, S., \& Ali, B. (2016). Effect of Islamic work ethics on job stress, turnover intention and employee well-being. Turnover Intention and Employee WellBeing. Retrieved 19 February 2016 from https://ssrn.com/abstract=2734766

Wahab, M.A. (2014). A cross-cultural comparison of Muslim and non-Muslim students in terms of Islamic work ethic characteristics. Australian Journal of Basic and Applied Sciences, 8(24), 301-307, 
Walumbwa, F.O., \& Schaubroeck, J. (2009). Leader personality traits and employee voice behaviour: Mediating roles of ethical leadership and work group psychological safety. Journal of Applied Psychology, 94(5), 1275-1286.

Wisker, Z.L., \& Rosinaite, V. (2016). The effect of religiosity and personality on work ethics: A case of Muslim managers. Science Journal of Business and Management, $4(1), 1-9$.

Womble, M.N., Labbé, E.E., \& Cochran, C.R. (2013). Spirituality and personality: Understanding their relationship to health resilience. Psychological Reports, 112(3), 706-715. https://doi.org/10.2466/02.07.PR0.112.3.706-715

Woods, S.A., \& Anderson, N.R. (2016). Toward a periodic table of personality: Mapping personality scales between the five-factor model and the circumplex model. Journal of Applied Psychology, 101(4), 582-604. https://doi.org/10.1037/ ap10000062

Xu, X., Yu, F., \& Shi, J. (2011). Ethical leadership and leaders' personalities. Social Behavior and Personality: An International Journal, 39(3), 361-368. https://doi. org/10.2224/sbp.2011.39.3.361

Yasein, M. (1998). Human nature in Islam. Kuala Lumpur: Zafar Sdn. Bhd.

Yousef, D. (2001). Islamic work ethic: A moderator between organizational commitment and job satisfaction in a cross-cultural context. Personal Review, 30, 152-69. https://doi.org/10.1108/00483480110380325

Zarabozo, J.A.M. (1999). Commentary of the forty hadith of Imam Nawawi (vol. 2, hadith 15). Boulder, USA: Al-Basheer Company for Publication and Translations. 
